\title{
Effect of Dietary Supplementation of Turmeric (Curcuma longa), Ginger (Zingiber officinale) and their Combination as Feed Additives in Gramapriya Chicks
}

\author{
K. Shibi Thomas*, V. Jayalalitha and P. N. Richard Jagatheesan
}

Veterinary University Training and Research Centre, Tamil Nadu Veterinary and Animal Sciences University (TANUVAS), 7/2, Kozhi Pannai Road, Kottapattu, Tiruchirappalli - 620 023, India

*Corresponding author

\begin{abstract}
A B S T R A C T
Keywords

Gramapriya, Production performance, Turmeric and Ginger

Article Info

Accepted:

24 July 2020

Available Online:

10 August 2020

The present study was carried out to assess the production performance on supplementation of turmeric, ginger and their combination in the diets of Gramapriya chicks (240 birds) for a period of 8 weeks. Six experimental diets were formulated with control diet $\left(\mathrm{T}_{1}\right)$ containing neither turmeric or ginger, $\mathrm{T}_{2}$ and $\mathrm{T}_{3}$ were fed diets containing 0.50 and $0.75 \%$ turmeric respectively, $\mathrm{T}_{4}$ and $\mathrm{T}_{5}$ fed diet containing 0.50 and $0.75 \%$ ginger respectively, $\mathrm{T}_{6}$ fed diet containing a combination of $0.50 \%$ ginger and $0.50 \%$ turmeric with commercial feed. The body weight gain was significantly $(\mathrm{P}<0.05)$ higher in $\mathrm{T}_{2}$ and $\mathrm{T}_{6}$. Feed intake was significantly $(\mathrm{P}<0.05)$ higher $\mathrm{T}_{1}$ and $\mathrm{T}_{2}$. Feed conversion ratio was significantly $(\mathrm{P}<0.05)$ better in $\mathrm{T}_{2}, \mathrm{~T}_{3}$ and $\mathrm{T}_{6}$ compared to other groups. Slaughter studies showed no significant difference between the treatments. The cost of production and return of birds was highly economical in treatment $\mathrm{T}_{2}$ as compared to other treatment groups. Supplementation of turmeric improves the growth performance of Gramapriya chicks when added at the rate of $0.50 \%$ in Gramapriya chicks.

\section{Introduction}

Natural growth promoters like plant extracts, can be used to feed the poultry without any adverse effect on the performance of birds. Beneficial properties of bioactive plant constituents comprises the stimulation of appetite and feed intake, the enhancement of endogenous digestive enzyme secretion, stimulation of immune response and antibacterial, antiviral and antioxidant action. Turmeric and ginger as natural growth

promoters can be used as an alternative of common artificial growth promoters like antibiotics. These natural growth promoters have wide range of medicinal properties with no residual side effects and are best alternatives to antibiotic growth promoters (Rahman et al., 2014). Beneficial effects of these substances in poultry nutrition are due to their high content of pharmacologically active compounds stimulating appetite and feed intake, improving endogenous digestive secretion and activating immune responses
\end{abstract}


(Nouzarian et al., 2011 and Toghyani et al., 2010). Therefore, the purpose of this research was to investigate the effect of different levels of turmeric and ginger powder alone and in combination on production performance in Gramapriya chicks.

\section{Materials and Methods}

Two hundred and forty (240) day-old, straight run Gramapriya chicks were divided into six groups, each having four replicates of 10 chicks each. These groups were allotted randomly into six dietary treatments i.e. $\mathrm{T}_{1}$ standard commercial desi chicken ration (control), $\mathrm{T}_{2}-$ control $+0.50 \%$ turmeric and $\mathrm{T}_{3}$ - control $+0.75 \%$ turmeric, $\mathrm{T}_{4}-$ control + $0.50 \%$ ginger, $\mathrm{T}_{5}-$ control $+0.75 \%$ ginger and $\mathrm{T}_{6}-\mathrm{a}$ combination of $0.50 \%$ turmeric and $0.50 \%$ ginger with control feed. The chicks were provided with optimum conditions of brooding and management.

The experiment was conducted for a period of eight weeks and the diet was formulated based on the commercial desi chick starter mash formulated as per BIS specifications (1992) containing 23 per cent crude protein and $2800 \mathrm{kcal}$ per $\mathrm{kg}$ metabolizable energy.

Individual body weight of chicks was recorded at weekly intervals and feed intake was recorded replicate wise at the end of each week. The average daily feed intake and feed conversion ratios were calculated utilizing the data on body weight gain and feed intake.

The cumulative results upto eight weeks were calculated for body weight gain, feed intake and feed conversion ratio. Mortality was recorded replicate-wise during the entire experimental period. The data collected on various parameters were statistically analysed as per the methods described by Snedecor and Cochran (1994).

\section{Results and Discussion}

Effect of Dietary Supplementation of Turmeric (Curcuma longa), Ginger (Zingiber officinale) and their combination as feed additives in Gramapriya chicks are shown in Table 1.

The body weight data upto eight weeks given in the table showed that the body weight was significantly $(\mathrm{P}<0.01)$ higher in 0.5 per cent turmeric supplemented group $\left(\mathrm{T}_{2}\right)$ followed by $\mathrm{T}_{6}(0.5$ per cent turmeric and ginger supplemented group) and $\mathrm{T}_{5}(0.75$ per cent ginger supplemented group). The lowest body weight was observed in control and $\mathrm{T}_{3}(0.75$ per cent turmeric supplemented group).

The cumulative weight gain upto eight weeks of age showed statistical differences between the treatments. The gain in weight was high $(\mathrm{P}<0.01) \mathrm{T}_{2}, \mathrm{~T}_{6}$ and $\mathrm{T}_{5}$ groups. This is in agreement with Mahanta et al., (2017), Okoleh et al., (2014) and Dieumou et al., (2009) reported combined herbal growth promoter, ginger and garlic supplementation improved body weight, weight gain and feed conversion ratio. The cumulative feed intake from the data revealed that the control group consumed significantly $(\mathrm{P}<0.05)$ higher feed intake, followed by $\mathrm{T}_{2}(0.5$ per cent turmeric supplemented group) and the lowest feed consumption was observed in $\mathrm{T}_{3}$ (0.75 per cent turmeric supplemented group). Mahanta et al. (2017) reported 2 per cent combined herbal growth promoter showed improved feed consumption, but 3 per cent combined herbal growth promoter showed decreased feed consumption.

The cumulative feed conversion ratio upon eight weeks indicated that $\mathrm{T}_{3}(0.75$ per turmeric supplemented group resulted in significantly superior $(\mathrm{P}<0.01)$ FCR followed by $\mathrm{T}_{2}(0.5$ per cent turmeric supplemented group) group. 
Table.1 Effect of Dietary Supplementation of Turmeric (Curcuma longa), Ginger (Zingiber officinale) and their combination as feed additives in Gramapriya chicks

\begin{tabular}{|c|c|c|c|c|c|c|c|}
\hline $\begin{array}{l}\text { Treatment } \\
\text { Groups }\end{array}$ & $\begin{array}{c}\text { Body Weight } \\
\text { (g) }\end{array}$ & $\begin{array}{c}\text { Body weight gain } \\
\text { (g) }\end{array}$ & $\begin{array}{c}\text { Feed } \\
\text { consumption (g) }\end{array}$ & $\begin{array}{c}\text { Feed conversion } \\
\text { ratio }\end{array}$ & $\begin{array}{c}\text { Ready to cook } \\
\text { yield (\%) }\end{array}$ & $\begin{array}{c}\text { Livability } \\
(\%)\end{array}$ & $\begin{array}{l}\text { Net profit per kg } \\
\text { live weight (Rs.) }\end{array}$ \\
\hline $\mathrm{T}_{1}$ & $\begin{array}{c}527.98^{\mathrm{B}} \\
\pm 11.58\end{array}$ & $\begin{array}{c}498.28^{\mathrm{B}} \\
\pm 11.51\end{array}$ & $\begin{array}{c}1903.12^{\mathrm{A}} \\
\pm 19.75\end{array}$ & $\begin{array}{l}3.82^{\mathrm{B}} \\
\pm 0.87\end{array}$ & $\begin{array}{l}70.76^{\mathrm{a}} \\
\pm 0.44\end{array}$ & $\begin{array}{l}97.50^{\mathrm{a}} \\
\pm 2.00\end{array}$ & 47.70 \\
\hline $\mathbf{T}_{2}$ & $\begin{array}{l}575.88^{\mathrm{A}} \\
\pm 13.90\end{array}$ & $\begin{array}{c}546.85^{\mathrm{A}} \\
\pm 13.90\end{array}$ & $\begin{array}{c}1850.08^{\mathrm{B}} \\
\pm 15.82\end{array}$ & $\begin{array}{l}3.38^{\mathrm{A}} \\
\pm 0.11\end{array}$ & $\begin{array}{l}71.45^{\mathrm{a}} \\
\pm 0.33\end{array}$ & $\begin{array}{l}97.50^{\mathrm{a}} \\
\pm 2.00\end{array}$ & 64.19 \\
\hline $\mathbf{T}_{3}$ & $\begin{array}{l}425.48^{C} \\
\pm 15.84\end{array}$ & $\begin{array}{l}395.50^{C} \\
\pm 15.95\end{array}$ & $\begin{array}{c}1693.41^{\mathrm{C}} \\
\pm 13.77\end{array}$ & $\begin{array}{l}4.28^{\mathrm{C}} \\
\pm 0.26\end{array}$ & $\begin{array}{l}69.99^{b} \\
\pm 0.77\end{array}$ & $\begin{array}{l}93.75^{\mathrm{b}} \\
\pm 1.00\end{array}$ & 23.26 \\
\hline $\mathbf{T}_{4}$ & $\begin{array}{l}542.20^{\mathrm{B}} \\
\pm 15.92\end{array}$ & $\begin{array}{c}513.18^{\mathrm{B}} \\
\pm 15.88\end{array}$ & $\begin{array}{c}1779.29^{\mathrm{B}} \\
\pm 17.53\end{array}$ & $\begin{array}{l}3.47^{\mathrm{B}} \\
\pm 0.21\end{array}$ & $\begin{array}{l}70.78^{\mathrm{a}} \\
\pm 0.60\end{array}$ & $\begin{array}{l}97.50^{\mathrm{a}} \\
\pm 2.06\end{array}$ & 56.51 \\
\hline $\mathbf{T}_{5}$ & $\begin{array}{l}549.68^{\mathrm{A}} \\
\pm 14.96\end{array}$ & $\begin{array}{l}520.68^{\mathrm{A}} \\
\pm 14.85\end{array}$ & $\begin{array}{c}1830.43^{\mathrm{B}} \\
\pm 18.43\end{array}$ & $\begin{array}{l}3.52^{\mathrm{A}} \\
\pm 0.10\end{array}$ & $\begin{array}{l}71.20^{\mathrm{a}} \\
\pm 0.11\end{array}$ & $\begin{array}{l}96.25^{\mathrm{a}} \\
\pm 1.00\end{array}$ & 58.46 \\
\hline $\mathbf{T}_{6}$ & $\begin{array}{l}564.05^{\mathrm{A}} \\
\pm 14.33\end{array}$ & $\begin{array}{c}534.08^{\mathrm{A}} \\
\pm 14.20\end{array}$ & $\begin{array}{c}1814.02^{\mathrm{B}} \\
\pm 15.32\end{array}$ & $\begin{array}{l}3.40^{\mathrm{A}} \\
\pm 0.14\end{array}$ & $\begin{array}{l}71.00^{\mathrm{a}} \\
\pm 0.56\end{array}$ & $\begin{array}{l}97.50^{\mathrm{a}} \\
\pm 2.00\end{array}$ & 62.07 \\
\hline
\end{tabular}

$\mathrm{n}=80$

Means within a column with different superscript small letters differ significantly $(\mathrm{P}<0.05)$

Means within a column with different superscript capital letters differ significantly $(\mathrm{P}<0.01)$ 
This is in accordance with Mahanta et al. (2017), Okoleh et al. (2014) and Dieumou et al., (2009).

The livability percentage was significantly lower in $\mathrm{T}_{3}(0.75$ per cent turmeric supplemented group), when compared to other groups, while there was no significant difference between the other groups. This result was in accordance to Mahanta et al. (2017) The net profit per kg live weight was high in $\mathrm{T}_{2}$ followed by $\mathrm{T}_{6}, \mathrm{~T}_{5}$ and $\mathrm{T}_{4}$, whereas the lowest profit was observed in $T_{3}$ and $T_{1}$. This result was in agreement with Choudhury (2018) who inferred that 0.75 per cent turmeric improved the gross profit per bird.

In conclusion $0.5 \%$ turmeric, $0.75 \%$ ginger and $0.5 \%$ turmeric and ginger combination with the control diet had significant influence on the body weight, body weight gain, feed consumption, feed conversion ratio, ready to cook yield, livability percentage and net profit per $\mathrm{kg}$ live weight from 0 to 8 weeks in Gramapriya chicks.

\section{Acknowledgement}

The author thanks Tamil Nadu Veterinary and Animal Sciences University, Chennai for providing necessary facilities for carrying out this research project.

\section{References}

Okoleh, V. U.O., Chukwu, G. C. and Adeolu, A. I. 2014. Effect of ground ginger and garlic on the growth performance, carcass quality and economics of production of broiler chickens. Global. J. of. BioScience and Biotech., Vol.3 (3): 225-229

Dieumou, F. E., Teguia, A., Kuiate, J. R., Tamokou, J. D., Fonge, N. B. and
Dongmo, M. C. 2009. Effects of ginger (Zingiber officinale) and garlic (Allium sativum) essential oils on growth performance and gut microbial population of broiler chickens. Livestock Res. Rural Dev. 21(8)

Mahanta, J.D., Borgohain, B., Mihir Sarma, D., Sapcota and Jakir Hussain. 2017. Effect of dietary supplementation of herbal growth promoter on performance of commercial broiler chicken. Indian J. Anim. Res., 51 (6): 1097-1100

Choudhury, D., Mahanta, J., Sapcota, D., Saikia, B., \& Islam, R. (2018). Effect of Dietary Supplementation of Turmeric (curcuma longa) Powder on the Performance of Commercial Broiler Chicken. International Journal of Livestock Research, 8(7), 182-191. doi: 10.5455/ijlr.20171129032810

Rahman, S., Mostofa, M., Fatema, M.N., Latif, M.A. and Afrin, S. 2014. Effect of neem leaves, turmeric and cinnamon extract as a growth promoter in broilers. Bangladesh Res. Publications J., 10(1): 7-13.

Nouzarian, R., Tabeidian, S.A., Toghyani, M., Ghalamkari, G. and Toghyani, M. 2011. Effect of turmeric powder on performance, carcass traits, humoral immune responses, and serum metabolites in broiler chickens. J. Ani. Feed Sci., 20: 389-400

Toghyani, M., Tohidi, M., Gheisari, A.A., and Tabeidian, S.A. 2010. Performance, immunity, serum biochemical and haematological parameters in broiler chicks fed dietary thyme as alternative for an antibiotic growth promoter. African J. Biotech., 9: 6819-6825.

Snedecor, G. W. and Cochran, W. G. (1994). Statistical Methods. $9^{\text {th }}$ Edn, Iowa state University press, Ames, USA. Iowa 50010 .

\section{How to cite this article:}

Shibi Thomas, K., V. Jayalalitha and Richard Jagatheesan, P. N. 2020. Effect of Dietary Supplementation of Turmeric (Curcuma longa), Ginger (Zingiber officinale) and their Combination as Feed Additives in Gramapriya Chicks. Int.J.Curr.Microbiol.App.Sci. 9(08): 3132-3135. doi: https://doi.org/10.20546/ijcmas.2020.908.356 